\title{
5: Migrant-worker remittances and Burma: an economic analysis of survey results
}

\author{
Sean Turnell, Alison Vicary and Wylie Bradford
}

\section{Introduction}

In recent years, great interest has awakened in the question of migrant remittances. The potential for remittances - a phenomenon hitherto regarded as of little consequence - to act as a means for poverty alleviation and economic development has increasingly come to enjoy a broad consensus. In the light of this, and the recognition that for many developing countries remittances constitute a larger and more stable source of foreign exchange than trade, investment or aid, a vast and growing literature on the topic has emerged. Notwithstanding this broad interest, there is, however, yet to appear any major study with respect to the question of migrant remittances to Burma.

This chapter seeks to at least partially redress this void by examining the extent, nature and pattern of remittances made by Burmese migrant workers in Thailand. Drawing on a survey of such workers conducted by the authors, it was found that remittances to Burma were large, were used disproportionately to ensure simple survival and were realised overwhelmingly via informal mechanisms. The last two attributes are a direct consequence of Burma's dysfunctional economy, which sadly also severely limits the gains to the country that remittances might otherwise bring.

For many developing countries, the remittances that their citizens send from abroad constitute a larger source of foreign exchange than international trade, aid or foreign investment. In 2006, such remittances, which were made by an estimated 150 million migrants across the globe, amounted to about \$US300 billion. In the same year, total aid and foreign direct investment (FDI) to developing countries were about \$US270 billion. The sheer volume of remittances, coupled with the fact that they are relatively stable and often counter-cyclical, makes them a potentially powerful source of development finance for receiving countries.

Many of the issues relating to remittance payments, however, are clouded by lack of data and considerable mystery as to the means by which they are made. The International Monetary Fund (IMF) records annual data for official worker remittance payments in its Balance of Payments Statistics Yearbook, but such 
data record only those payments that are made through official banking channels. Remittances that flow through private and unofficial channels, and via a variety of non-banking instruments, are not recorded. This is problematic for many countries and circumstances, but it is especially significant for migrants from countries in which trust in banks is mostly absent.

In Burma, there is all pervasive mistrust - not only in banks, but in just about all of the country's institutions, financial and otherwise. Add to this an oppressive, secretive state and we have a comprehensive package of circumstances that makes data for the country highly unreliable. According to the IMF, official worker remittances to Burma totalled \$US81.3 million in 2004 (the latest data available), from which must be deducted the remittances of foreign workers in Burma (mostly working for multinational corporations and international aid agencies) of \$US24.5 million-delivering a net remittance surplus of \$US56.8 million. Of course, these official flows (the inward component of which is due largely to funds sent home by Burmese merchant seaman) greatly understate the remittances sent by Burma's estimated two million or so migrant workers and refugees who live outside its borders, and which are made (overwhelmingly) via informal payment mechanisms of various types. Such remittances are likely to be three to four times the official flows and their existence represents a lifeline that permits the survival of many thousands of families in Burma.

The importance of the remittance issue has triggered a vast and growing literature on the topic and great interest from multilateral agencies such as the World Bank, the IMF and the Organisation for Economic Cooperation and Development (OECD). Remittances have also come to the attention of international banks and other financial institutions, with their eye for market opportunities, anxious to grab a share of this potentially lucrative trade. No study, however, has yet been undertaken in relation to Burma, especially with respect to the informal remittance channels that dominate most payments into and out of the country.

The purpose of this chapter, accordingly, is to attempt to remedy this neglect at least partially by shedding some light on the nature, patterns and magnitude of the remittances sent by Burmese migrant workers and refugees in Thailand. Central to this analysis is the survey conducted by the authors across 2002-03. The use of a survey is necessary in the context of Burma since, firstly and simply, information and data scarcely exist in any other form. A survey is, however, also useful for other reasons when exploring remittances, including the fact that it can shed light on the uses of funds sent, the incentives faced by senders and recipients and other salient facts beyond simply financial data. Similar studies using household and individual survey data have yielded much information regarding remittances in other countries and regions, but this is the first such study regarding Burma and its population in Thailand. 
The chapter is divided into seven sections. It begins by considering the broader context of remittances and why they are important - for the individuals directly concerned as senders and receivers and, more generally, for recipient countries. Section three considers the types of instruments and channels through which remittances are sent. The focus is particularly on informal remittance devices. As will become clear, such devices are not only the most important means by far through which remittances are sent into Burma, they are the least understood. Section four examines why migrants are often likely to choose informal remittance devices, despite the benefits formal methods confer. Section five details the results of our survey and examines the amounts sent, the costs of sending, the end uses of funds and methods of delivery, as well as the factors that determine these. Section six offers some conjectures on the survey results, relating the experiences revealed to those of other people and situations and highlighting the differences that set Burma apart. The chapter concludes with some thoughts about how Burma's economic mismanagement squanders the development potential of the country's remittance flows.

\section{The importance of remittances}

The increasing attention paid to the question of migrant remittances comes from the realisation of the important role they play in poverty alleviation and, circumstances permitting, economic development more broadly. The former is most obvious in the way the circumstances of individuals are directly transformed; the latter operates via a collective response much dependent on the existence of institutions that can leverage remittances to create true 'development finance'.

\section{Individual poverty alleviation}

Remittance payments directly alleviate the poverty of the individuals and households to whom they are sent. Forming a relatively stable source of income independent of the (often dire) local economy of recipient families, remittances offer a lifeline to millions in the most vulnerable groups across the developing world. Moreover - and unlike other financial flows to developing countries that stream through government agencies and non-governmental organisations (NGOs) - remittance payments are targeted precisely to the needs and desires of their receivers. It is not aid agencies or governments that decide when, where or why remittance incomes are spent, but the recipients themselves.

As with other 'novel' devices of promise in the field of economic development (micro-finance and civil-society promotion being other examples), relatively little in the way of empirical work has been undertaken on the impact of remittances on poverty alleviation. The empirical work that has been done, however, supports the positive picture painted above and in the countless anecdotes that dominate the literature. For instance, a 71-country study 
undertaken by Adams and Page (2005:1646) concluded that remittances 'reduce the level, depth, and severity of poverty' of receivers and their communities. Likewise, Ratha (2005) found that remittance flows lowered the proportion of people living in absolute poverty in Uganda, Bangladesh and Ghana by 11, 6 and 5 per cent, respectively. Gupta et al. (2007) find that a 10 per cent increase in a country's remittances-to-GDP ratio corresponds with a fall in the percentage of people living on less than \$US1 a day of just more than 1 per cent. The World Bank (2003), the OECD's Financial Action Task Force (2005) and Spatafora (2005) also find reductions in absolute poverty among remittance receivers. Meanwhile, studies such as López-Córdova (2005) and Hildebrandt and McKenzie (2005) find positive associations between remittances and poverty-reduction 'proxies' such as lower infant mortality and higher birth rates. ${ }^{1}$

The ways in which remittances alleviate the poverty of individuals are, in the 'first round' of effects, direct and fairly obvious. They include the following.

- 'Survivalist' income supplementation. For many recipients, remittances provide food security, shelter, clothing and other basic needs.

- Consumption 'smoothing'. Many recipients of remittances, especially in rural areas, have highly variable incomes. Remittances allow better matching of incomes and spending, the misalignment of which otherwise threatens survival and/or the taking on of debt.

- Education. In many developing countries, education is expensive at all levels, whatever the formal commitments of the State. Remittances can allow for the payment of school fees and can provide the wherewithal for children to attend school rather than working for family survival. ${ }^{2}$

- Housing. The use of remittances for the construction, upgrading and repair of houses is prominent in many widely different circumstances.

- Health. Remittances can be employed to access preventive and ameliorative health care. As with education, affordable health care is often unavailable in many remittance-recipient countries.

- Debt. Being in thrall to moneylenders is an all-too-common experience for many in the developing world. Remittances provide for the repayment of debts and for the means to avoid the taking on of debt by providing alternative income and asset streams.

- Social spending. Day-to-day needs include various 'social' expenditures that are culturally unavoidable. Remittances can be employed to meet marriage expenses and religious obligations and, less happily but even more unavoidable, funeral and related costs.

- Consumer goods. Remittances allow for the purchase of consumer goods, from the most humble and labour saving, to those that entertain and make for a richer life. 
Of course, the extent to which remittances reduce poverty is explicably bound up in how they are used. Typically for poorer recipients, remittance payments are used for basic survival, consumption, housing, health and education, as per above. Once these needs are met, however, remittances can be 'invested' whereupon they provide 'second-round' impacts on poverty into the future. Of course, education and some health expenditure can legitimately be thought of as constituting investment, but important in this context is the extent to which remittances can be used to create income-generating activities. Expenditure on agricultural equipment and fertilisers, vehicles, retail stock and equipment and on land improvement are not uncommon forms of investment of remittance earnings. ${ }^{3}$

\section{Broader concerns: remittances and economic development}

Remittance income does not benefit just individual recipients, it benefits the local and national economies in which they live. Indeed, the spending allowed by remittances has a multiplied effect on local economies - as funds subsequently spent create incomes for others and stimulate economic activity generally. Beyond such multiplier effects, however, are other factors conducive to economic growth and stability.

- Remittances can provide receiving countries with much-needed foreign exchange. As noted at the outset of this chapter, remittances are a more stable and reliable form of foreign earnings in many developing countries than either FDI or aid flows, and help alleviate the balance-of-payments and debt crises that are often a characteristic of such countries. In this sense, they are also a potentially stabilising factor for national currencies and can provide developing countries with lower borrowing costs by presenting them with a stable flow of foreign exchange 'collateral'. 4

- Adding to the appeal of remittance flows to local and national economies is the fact that their frequency and magnitude tend to be counter-cyclical. Economic distress in the home country-precisely the scenario least conducive to other financial flows such as FDI-inspires migrant workers (for altruistic reasons or to protect their own economic interests at home) to increase the volume of funds they remit. Thus, just as remittances allow consumption smoothing for individual households, in this sense they provide a potentially stabilising stream of earnings for national economies too.

- Remittances provide a potential boon for a country's financial development: a stream of earnings to be tapped for saving and for leveraging through formal credit and other products. ${ }^{5}$ The existence of links between financial-sector development and economic growth now enjoys a broad consensus, and there is also growing acceptance that better financial institutions lead to lower levels of poverty and inequality. 'Leveraging up' remittances through formal financial institutions (FIs) is important since, by 
themselves, remittance flows do not solve the structural financial constraints faced by many developing countries. FIs allow remittance recipients to access credit to finance business projects, smooth consumption and so on, and to establish a financial and savings culture more broadly. 'Banking the unbanked' is one of the prime objectives of the micro-finance 'movement', but it is an objective similarly enhanced by FIs bundling remittance payments into savings and (ultimately) loan products through which investment can be activated. ${ }^{7}$ Of course, FIs also stand to benefit individually in the longer run through the establishment, via remittance products, of customer relationships with people who are often the most enterprising members of society. In Latin America, about one-fifth of remittance senders become bank clients (Orozco and Fedewa 2006:21). ${ }^{8}$

- The 'leveraging up' of remittances via financial institutions is the policy of individual FIs and micro-finance operators, as well as significant industry representative groups such as the World Council of Credit Unions (WOCCU). The latter's International Remittance Network has enabled hundreds of credit unions (in sending and receiving countries, mostly in the Americas) to participate in the remittance business in collaboration with money-transfer firms (WOCCU n.d.). These firms are relatively expensive, however, and their fees are a significant drain on the margin of funds available for saving. ${ }^{9}$ Help is available from various multilateral agencies and NGOs in developing remittance products and linking them with micro-finance - in which context the International Fund for Agricultural Development (IFAD) of the United Nations, USAID (which is providing funds for the WOCCU initiatives) and the Ford and Rockefeller Foundations are especially prominent.

\section{Negative aspects of remittances}

The overwhelming narrative of the remittances issue is a positive one, but it is important to recognise that such payments are the flipside of what is also the loss of labour abroad. Moreover, this labour is often the most highly skilled - the manifestation of the 'brain drain' that is a characteristic of the interaction between the rich and the poor worlds more broadly. Such labour migration causes skills shortages at home and imposes great human costs that come from people forced to be away from their families and their communities. ${ }^{10}$ The existence of substantial labour migration from a country, and the remittance flows created as a consequence, is often a most eloquent statement about the lack of economic opportunities at home.

A concern sometimes voiced about remittances is that they might promote a variant of the so-called 'Dutch disease'. A phenomenon identified with respect to the Netherlands in the 1960s, Dutch disease is the possibility that foreign exchange flows in one area (gas, in the case of the Netherlands) could result in the overvaluation of a country's exchange rate and, as a consequence, make 
other areas of its economy uncompetitive. Given the often-chaotic nature of foreign-exchange arrangements in developing countries, Dutch disease effects with respect to remittances are almost certainly overstated. Certainly, as a problem, it would be swamped by far more significant ones in the case of Burma's multiple exchange-rate arrangements - otherwise variously guided by government fiat (in the case of the 'official' rate) and the wild swings of sentiment that drive the unofficial value of the kyat.

\section{Remittance channels and instruments}

A characteristic of the global remittances trade is the prominence of informal as well as formal funds-transfer methods and instruments. Formality and informality are, of course, relative concepts in many developing countries (and especially in one such as Burma). For the purposes here, however, and consistent with the categories adopted in many countries and multilateral agencies, formal transfers and informal transfers are distinguished by the fact that the former operates via regulated institutions and the latter via entities that operate outside the regulated financial system (World Bank 2003:23). Typically, banks, dedicated money-transfer firms, other financial institutions, post and telegraph services and so on dominate formal transfers. Informal transfers are impossible to categorise narrowly and include everything from hundi systems, couriers and traders and ethnic store networks, to simply carrying money in person across borders. As the survey results show, the relative importance of formal versus informal methods varies wildly according to circumstance. ${ }^{11}$

\section{Formal funds-transfer schemes}

Funds-transfer schemes normally provide the least risky, but also the most expensive way of sending remittances, with charges typically ranging between 10 and 15 per cent of the principal transferred (World Bank 2006:135). The funds-transfer sector is dominated by dedicated money-transfer firms, of which Western Union (which commands an estimated 15 per cent of the global remittances business) is the giant (with more than 300000 agents in more than 200 countries). ${ }^{12}$ In recent times, however, formal banks have made inroads into the market share of firms such as Western Union. This is the result of a number of factors (including greater migrant familiarity with banks), but not least the aggressive entry into remittance markets by banks themselves. The latter include some of the most prominent global bank 'brands', as well as newly privatised and commercialised banks in migrants' home countries. The trend is especially apparent in the highly lucrative Latin American remittances business, hitherto very much the preserve of Western Union and its peers. Representative of the phenomenon is the situation in the remittance trade to Mexico, where banks increased their market share from 4 to 17 per cent between 1993 and 2000 (Amuedo-Dorantes et al. 2005:52). 


\section{Informal funds-transfer schemes}

Informal funds-transfer schemes are used by migrants all over the world where, legal status of sender aside, they thrive because financial institutions in their home country are few, weak or not accessible. If we add to this the fact that many migrant workers come from rural areas and have no familiarity with banks in the first instance, there is a situation in which informal transfer systems have managed to survive in a world of otherwise growing financial-sector formality and sophistication. The relative importance of formal/informal transfer systems varies widely. Informal mechanisms account for probably only 5-20 per cent of remittances in Latin America, but in Sub-Saharan Africa they probably make up 45-65 per cent of the trade (World Bank 2003; Freund and Spatafora 2005).

As noted above, there are many devices that come under the informal funds-transfer rubric. The nature and modus operandi of the most important of these are the issues to which this chapter now turns.

\section{Hundi}

So labelled in Burma, hundi arrangements are known under a variety of names in the many countries and cultures in which they operate. Known variously as 'hawala' (in the Arabic-speaking world), 'chiao hui' (in China) and 'poey kwan' (in Thailand), hundi is an ancient device in which monetary value is transferred via a network of dealers or brokers from one location to another. While much mystery is sometimes made of hundi schemes, the mechanics of their operations are relatively straightforward - as can be seen in the following (equally simple) example:

Person A, a Burmese migrant worker in Thailand, desires to send money home to her family in Burma. To do this, she approaches a hundi dealer whom she knows and pays them, in baht, the amount she wants sent. The hundi dealer now contacts their counterpart (another hundi dealer) in Burma, who pays Person A's family in kyat. The amount received by the family will be the kyat equivalent of that paid by Person A in baht, less an amount that represents the commission charged by the two hundi dealers. As far as Person A is concerned, the transaction is now complete. She has sent her money home.

A number of matters remain unresolved in the above example, of course. First, the hundi dealer in Thailand now owes the hundi dealer in Burma for the remittance payment. How will this be settled? There are a number of ways, depending on the circumstances. One of the most common methods (highly applicable in the context of Burma) is that the debt between the two hundi dealers will be settled in goods. Many hundi dealers are, in fact, shops and traders of various kinds, with hundi dealing a 'side' activity. In the case above, therefore, goods to the value of the remittance debt will ultimately make their way from 
the hundi dealer in Thailand to their Burma counterpart. In cases such as Burma, with little in the way of domestic production of complex consumer items, the importation of goods presents a ready avenue for hundi settlements. Beyond such 'in-kind' settlements, however, are a number of other reconciliation devices. Most obviously, in circumstances in which financial institutions are accessible to hundi dealers (if not to hundi customers), funds could be sent directly via banks or money-transfer firms. Such circumstances are mostly unlikely, however, which opens the way for settlement in near-monetary commodities such as gold, precious stones and (sometimes) contraband such as narcotics.

A related issue is the question of foreign exchange flows - or, rather, as the example above shows, their absence. Hundi mechanisms, because they are characterised by 'netting' or 'book-transfer' methodologies, transfer value rather than currencies. Accordingly, and as long as settlement between the hundi dealers is not ultimately made in cash, hundi systems do not deliver foreign exchange to recipient countries. As this chapter explains, this has implications - not least in that it hinders the development potential of remittances via the 'leveraging up' of such flows through formal financial institutions. Since hundi systems hide financial flows between countries, they can also be used for money laundering. ${ }^{13}$

In practice, various complications come into the simple picture painted above, most of which, however, only add to the appeal of the hundi system. For instance, to ensure security, the hundi dealer in Thailand usually gives the Burmese migrant worker an authentication code. This code is communicated by the hundi dealer to their equivalent in Burma (usually by phone) and by the Burmese migrant worker to their beneficiary in Burma (also usually by phone). This beneficiary must reveal the authentication code to the hundi dealer in Burma in order to receive the remittance payment. Another complication to the simplified example above is that often the hundi 'commission' is not an explicit independent 'charge', but an implicit fee levied via discounting the (baht/kyat) exchange rate through which the remittances are calculated. Finally, and as is readily apparent from the above, at the core of the hundi system is trust. For the senders and receivers of remittances, such trust is won by observation of the system in successful operation and repeated dealings. Among hundi dealers themselves, trust is often based on kith and kin relationships. Accordingly, it is no surprise that hundi dealers everywhere tend to assemble networks based on ethnicity. Given too that hundi operations are often a sideline to trading generally, so-called 'ethnic stores' are often integral to hundi networks.

\section{Personal delivery}

In the age of the Internet, the delivery of remittance payments by hand-via friends, family members, couriers and traders - remains surprisingly resilient in the remittance trade around the world, and not just in the poorest of countries. Suro et al. (2002), for instance, found that personal delivery accounted for 10 
per cent of remittance payments to Latin America - a market otherwise dominated by money-transfer firms, banks and other financial institutions. ${ }^{14}$

Internationally, personal delivery ranks among the cheapest of remittance systems, but it is also the most vulnerable to theft and accordingly requires high levels of trust. It is therefore often the case that the 'courier' is a family member, a close friend or, in the case of the Thai-Burma border trade, a trader dependent for their own security on the discretion of their customers on either side of a dangerous frontier.

\section{Choosing between formal and informal transfer schemes}

One of the major barriers to the use of formal transfer mechanisms is, not surprisingly, the legal status of the sender. If a migrant worker is without legal status in the host country, using a bank or a formal money-transfer firm (where formal identification is usually a requirement) is difficult and risky. In Thailand, foreigners wanting to access a bank need to set up a 'non-resident' baht bank account, which in turn requires the production of a passport, a long-term visa or work permit, as well as a letter of recommendation from an employer, existing bank customer or from the customer's bank abroad. In contrast, informal funds transfers require minimal paperwork and are 'anonymous' as far as government authorities are concerned.

The legal status of the sender is likely the most significant reason for the use of informal funds transfers in most circumstances. There are other reasons, however, including the following.

- A cultural or historical familiarity with informal funds-transfer mechanisms and, conversely, unfamiliarity with formal financial institutions such as banks. Naturally, many hundi dealers and the like are themselves members of remitting and recipient communities.

- Informal funds transfers are based on trust networks of personal contacts - precisely the same sorts of networks and contacts that are important in enabling cross-border migration (such as that between Thailand and Burma) in the first place.

- A lack of formal financial institutions in the (often predominantly rural) areas where recipients live. In the literature, this is sometimes referred to as the 'last-mile' problem (World Bank 2003:29). Such problems can dictate the use of informal funds transfers, even if formal channels are available and cost effective for the sender - that is, in the so-called 'first mile'.

- Informal funds-transfer systems tend to be extraordinarily resilient in the face of all manner of instability, including conflict and civil wars, economic crises, weak and unreliable monetary and financial systems, the levying of economic sanctions and other events than can affect the formal economy and what the World Bank (2003) calls 'national infrastructure'. 
- Informal funds transfers move funds remarkably quickly. The typical experience globally is that even people in very remote areas receive payment via informal funds transfers within 24 hours.

- Informal funds transfers are often the cheapest remittance channel. Estimates vary, but informal funds transfers typically cost between 2 and 10 per cent of the transaction principal (Adams 2006; World Bank 2003). Informal funds transfers do not have to meet regulatory or compliance costs and the like, nor do their promoters typically have much in the way of expensive infrastructure.

- In many countries and circumstances, 'quasi-legal' economic activity (such as informal funds transfers) is the dominant form of business. In such circumstances, commerce runs along functional rather than strictly 'legal' channels. Informal funds transfers are illegal in many places; their functionality is a product, however, of their widespread and everyday acceptance.

\section{Survey findings}

The data underlying this analysis of Burmese migrant worker remittances are drawn from a survey of about 1000 such workers undertaken by the authors in 2002-03. The survey was conducted in 12 provinces of Thailand, selected according to their relative importance as areas of settlement and employment of

Burmese. ${ }^{15}$ By far the majority of the workers interviewed had fled the violent repression in Burma that followed the uprisings of 1988, with most arriving during the latter half of the 1990s. The survey revealed that prominent in the list of factors driving the flight of the Burmese, in addition to fleeing the country's political repression and civil wars, was Burma's grinding poverty and lack of economic opportunities. Not unexpectedly, given their proximity to Thailand and the long experience of conflict in these areas, the majority of the workers surveyed (and Burmese in Thailand generally) were from rural areas of Burma's Karen, Mon and Shan States, as well from Tenasserim Division. The median income for Burmese migrant workers employed in their first job in Thailand was about 2500 baht (Bt) a month. Only 40 per cent of the workers surveyed were in possession of a formal work permit conferring legal employment status. Workers holding work permits were over-represented in jobs earning more than Bt5000 a month, while the converse was true for those earning below Bt1000. The workers in the survey were employed across a number of industries, including fishing, construction, retail trade, hotels and restaurants, household service, food processing, agriculture, forestry and quarrying. Incomes earned varied widely across these industries, the highest paid being those engaged in quarrying and the lowest in agriculture and forestry. A majority (62 per cent) of those surveyed were men. 


\section{Results: amounts sent}

As can be seen from Table 5.1, the median amount sent home by the 524 survey recipients who declared making remittance payments was Bt15 000 (about \$US575). This is an annual aggregate figure, nominated by the respondents as the total they sent home for the previous 12 months. The maximum amount sent by any single worker was Bt3 million, while the lowest non-zero annual remittance total was Bt3000.

Table 5.1 Summary statistics for remittances $(n=524 / 1023)$

\begin{tabular}{|c|c|}
\hline Summary measure & Value (baht) \\
\hline Sum & 10034083 \\
\hline Mean & 19149 \\
\hline Median & 15000 \\
\hline Mode & 10000 \\
\hline Aggregate ratio to income & 0.38 \\
\hline
\end{tabular}

The aggregate ratio of annual remittance payments to annual disposable income of 38 per cent is quite high relative to experiences elsewhere. Moreover, the ratio is almost certainly understated since the survey includes bands of income rather than discrete amounts and the calculation here includes income at the top of each nominated band. Estimates for the United States suggest that migrant workers send home between 20 and 40 per cent of their aggregate earnings, but the concentration in most studies is between 20 and 25 per cent (Orozco 2006; Amuedo-Dorantes et al. 2005).

Should the survey results be anywhere near representative of the million or so Burmese in Thailand, the aggregate annual flows of remittances to Burma in 2002/03 from this source would have been in the order of \$US300 million. ${ }^{16}$ Such flows are nearly five times Burma's 'official' remittance payments for the year, more than twice the amount of FDI received and they would represent about 5 per cent of Burma's GDP. ${ }^{17}$ Of course, these numbers are very rough, but they give some idea of the magnitude of the likely remittance payments to Burma and the potential they could yield for the country's economy more broadly.

Not unexpectedly, individual remittances from migrant workers tend to rise with income (de la Garza and Lowell 2004). As can be seen in Figure 5.1, the survey data are consistent with this general rule. What appear to be strong falls at various income categories in the graph is largely a statistical anomaly-due to greater sampling variability caused by small numbers of respondents at these incomes. 
Figure 5.1 Remittances by income group

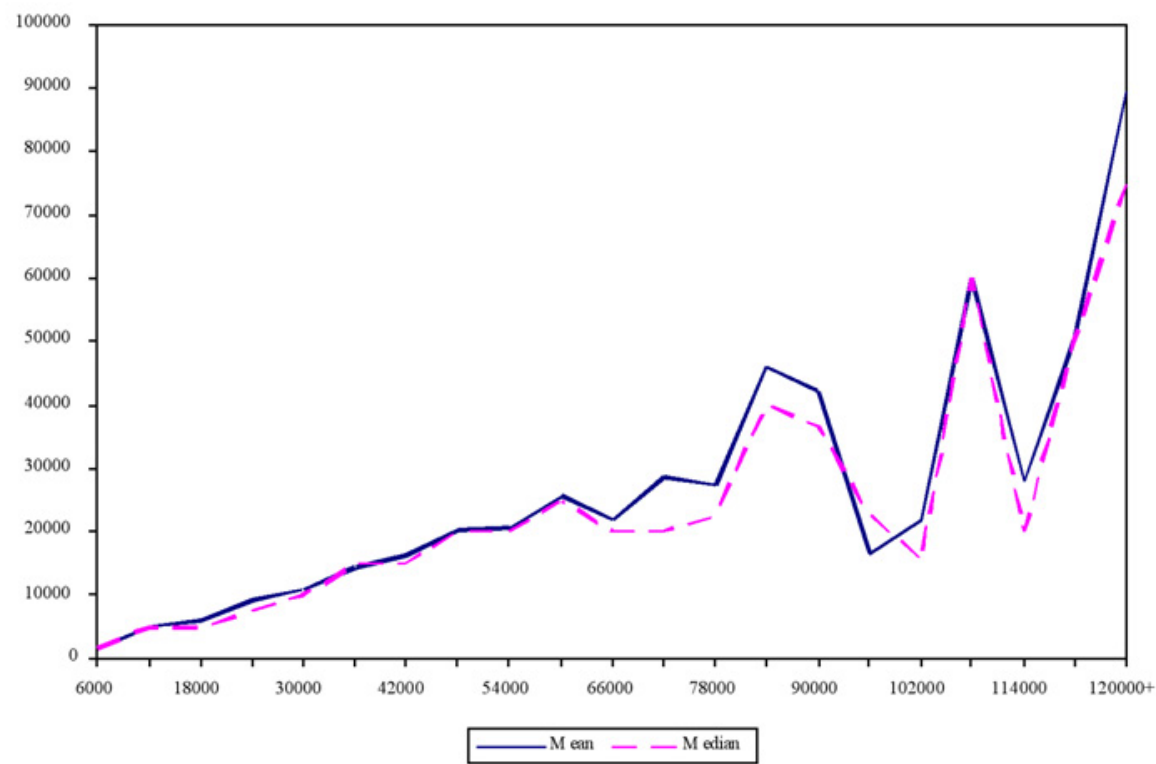

Maximum baht disposable income 2003

Figure 5.2 Remittances by duration of residence in Thailand

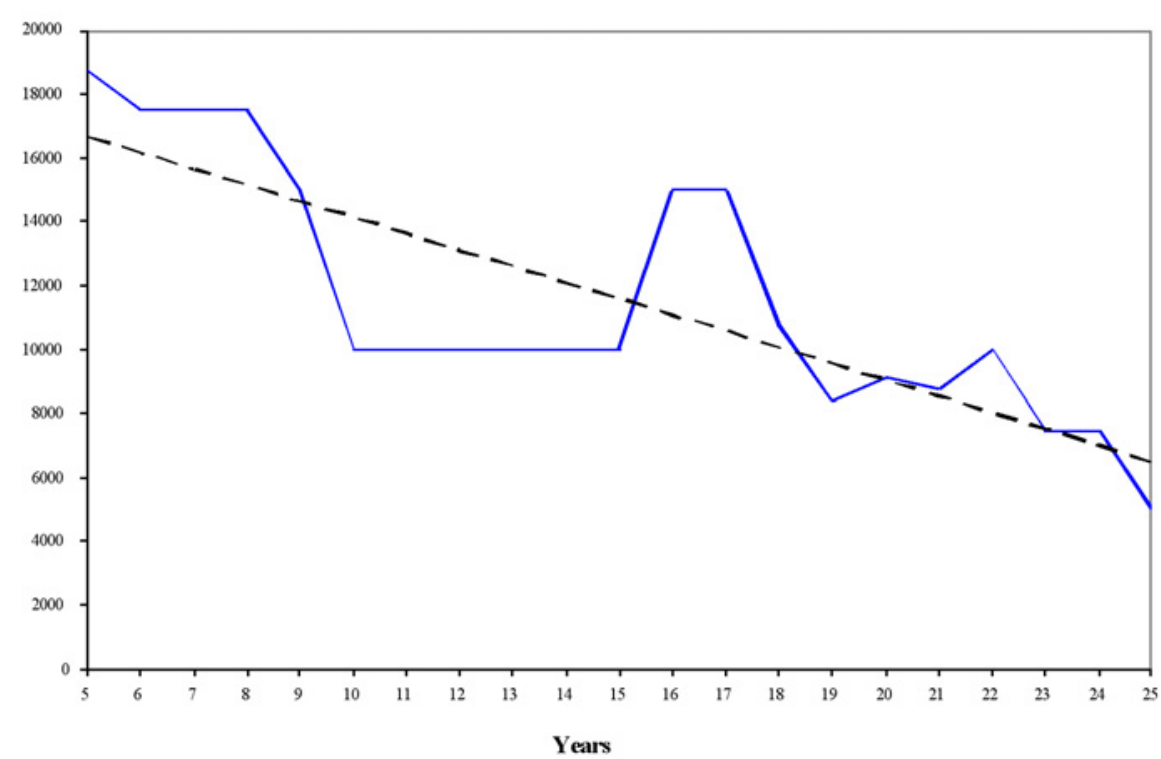


A phenomenon identified in other places and contexts is that individual remittances decline with time, usually as a consequence of migrants putting down roots in their host country and losing touch with their former home. As Figure 5.2 indicates, such a decline in remittances is evident from our data too. The authors are, however, reluctant to draw the conventional inference since few Burmese establish de jure permanent settlement in Thailand (if not de facto residence for considerable periods). It is possible, for instance, that in Burma's circumstances the depicted decline in remittances for individuals across time is less a function of them establishing themselves in Thailand than the fact that family members might themselves have subsequently left Burma. In this case, there could be no-one left to send remittances to.

\section{Uses for remittances}

What are Burmese migrant-worker remittances used for? Migrant-worker remittances everywhere are made and subsequently spent according to a hierarchy of needs. According to this survey, the remittances Burmese workers send from Thailand are used overwhelmingly to assist their families in basic survival. Some 96 per cent of respondents nominated this as their first order of priority. Indeed, many nominated family survival as their only motivation, with some taking the opportunity to annotate on our survey documents the living conditions faced by their families back in Burma.

As can be seen from Figure 5.3, other purposes (nominated on the survey itself according to priorities common in other contexts and circumstances) were negligible motivating factors. Such motivations, however minor, included (in order of importance assigned by survey respondents): to purchase or develop farm land; to establish a business; to meet education expenses; to repay debt; to hire workers in Burma; and to purchase consumer goods.

Figure 5.3 Remittances by intended recipient use

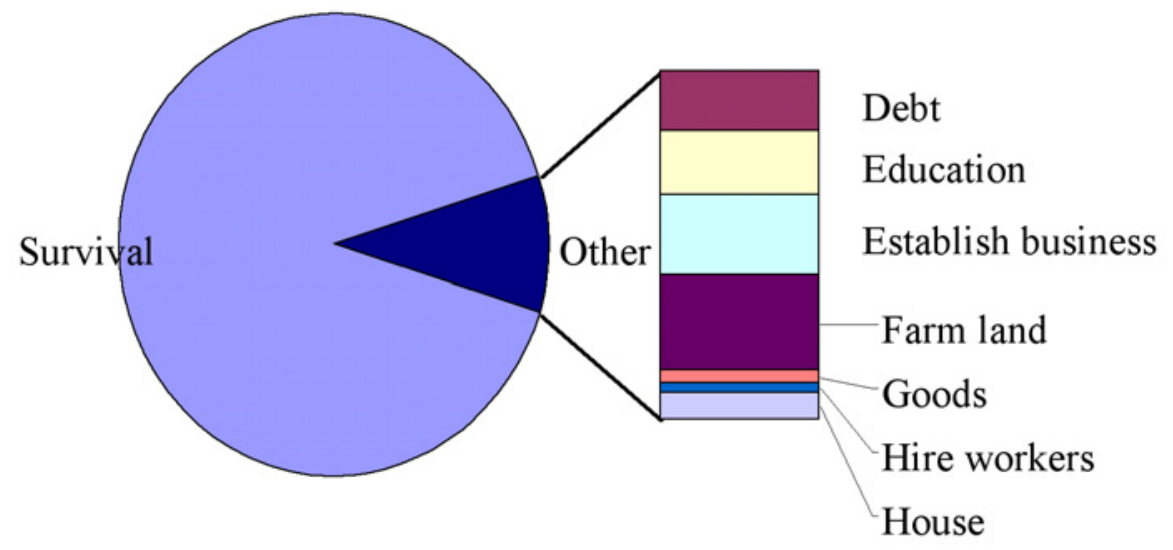




\section{Figure 5.4 Remittance share by transfer method}

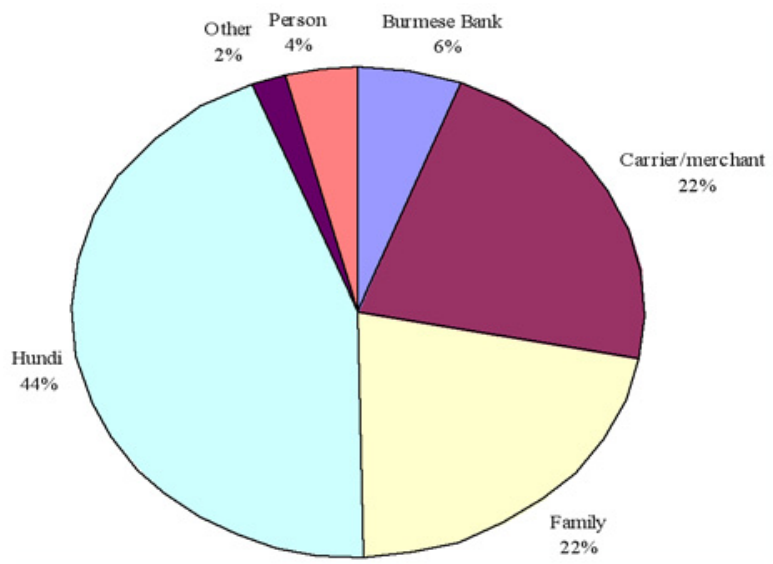

\section{Methods and instruments}

The most noteworthy fact revealed by the survey of remittance methods and instruments is the overwhelming dominance of informal funds transfers. As demonstrated in Figure 5.4, 94 per cent of respondents in the survey reported that they made their remittance payments via informal funds transfers. Within informal funds transfers, hundi was the dominant device (twice as large as any other), but significant proportions were simply carried into Burma by hand by either close family members or carriers and merchants. The nearly one-quarter share taken up by carriers and merchants could reflect a number of factors: most obviously, the porous nature of the Thai-Burma border, but also a possible remittance role played by brokers who bring many Burmese into Thailand in the first place. The small share ( 6 per cent) of migrant workers who carry their payments back into Burma themselves likely reflects the fact that Burma's political situation dictates that few migrants are in a position to return home.

The dominance of hundi is not unexpected since, as alluded to above, it is a device particularly well suited to the situation faced by Burmese migrant workers. Using banks is almost impossible for most Burmese in Thailand because of the level of documentation required (as noted earlier, to use banks in Thailand, foreigners must establish a 'non-resident' baht bank account, which in turn requires a passport, a long-term visa or work permit, as well as letters of recommendation). Meanwhile, Burma's political situation means that other formal transfer mechanisms (such as money-transfer firms) are not functional in the trade. Accordingly, and unless funds are physically carried across the border, hundi is the device preferred by most. As noted earlier, hundi relies on trust. Significantly then, the survey revealed no cases of fraud and numerous anecdotes of hundi dealer selection being based on positive word of mouth, reinforced by subsequent repeated dealings. 
Other reasons for the dominance of hundi almost certainly include historical familiarity and cost. Hundi systems have a long history in Burma and in the colonial era they were championed by the Chettiar moneylenders, who, for nearly a century, were the country's principal financiers. The Chettiars used hundi systems not only to transfer funds (domestically as well as internationally), but to provide a (critically important) credit instrument to Burmese cultivators. In this context, the Chettiars provided credit simply by making payments in advance of the hundi sender's remittance - turning a hundi into something akin to the 'bill of exchange' long familiar in the West. Just like bills of exchange elsewhere, Western banks operating in Burma even 'discounted' hundis (that is, buying them at less than face value and thus providing the seller with finance at a discount 'rate' equivalent to an interest charge), thus connecting colonial Burma's informal financial system with that of its formal and international equivalent - and providing Burma with the finance that went towards the transformation of the Irrawaddy (Ayeyarwady) Delta into the largest rice-growing region in the world. Eventually, in its perennial quest to create a viable tax system in Burma, the colonial government even supplied a specially authorised hundi 'chapter', upon which was payable a stamp duty. The Chettiars were effectively expelled from Burma post independence, but the hundi lived on as a principal device for trade throughout the country and beyond it. With the Chettiars gone, hundi in Burma ceased to be identified with any particular ethnic group. This legacy today separates the experience of hundi in Burma from those of many other parts of South-East Asia, where the trade is greatly dominated by ethnic Chinese and their businesses. ${ }^{18}$

While precision in this context is not remotely possible, the authors estimate that about 40 per cent of all of Burma's 'legal' border trade is conducted via hundi, while more than 90 per cent of strictly illegal business (smuggling notably) is undertaken through hundi channels. Following the emergence of private banks in Burma in the early 1990s, hundi entered a period of decline as a remittance and credit device in the country. It has re-emerged strongly since the collapse of the most important of these banks in the financial crisis of 2002-03.

The survey respondents reported that the average cost of sending a hundi amounted to about 5 to 10 per cent of the principal sent (levied mostly via a discount/premium on the baht/kyat exchange rate). As noted earlier in this chapter, formal money-transfer firms typically charge between 10 and 15 per cent.

The small ( 6 per cent) share of remittances sent into Burma via formal banks is confined almost exclusively to migrant workers sending funds to Putao in Kachin State. Putao is a hill town that can be reached only by air. This, coupled with the fact that it is also home to four battalions of the Tatmadaw (army), conceivably 
makes the physical carrying of funds from Thailand, and that sent via hundi, highly vulnerable to 'official' expropriation.

Other regional variations of remittance method are also apparent in our survey data. The physical carrying of funds, for instance, is the overwhelming practice of those sending funds to Shan State. In contrast, almost 100 per cent of workers remitting funds to Tenasserim (Tanyintharyi) and Mon State use hundi.

Hundi is the dominant remittance device according to the number of Burmese migrant workers using it, but it is also the favoured instrument according to value. In this context, hundi's lead over other mechanisms is marginal, and to some extent the most remarkable fact observable in Figure 5.5 is the high degree of equality of the various instruments by value (the numerals written in each of the columns below represent the raw numbers of individuals nominating each of the remittance devices).

\section{Figure 5.5 Remittance magnitudes by method}

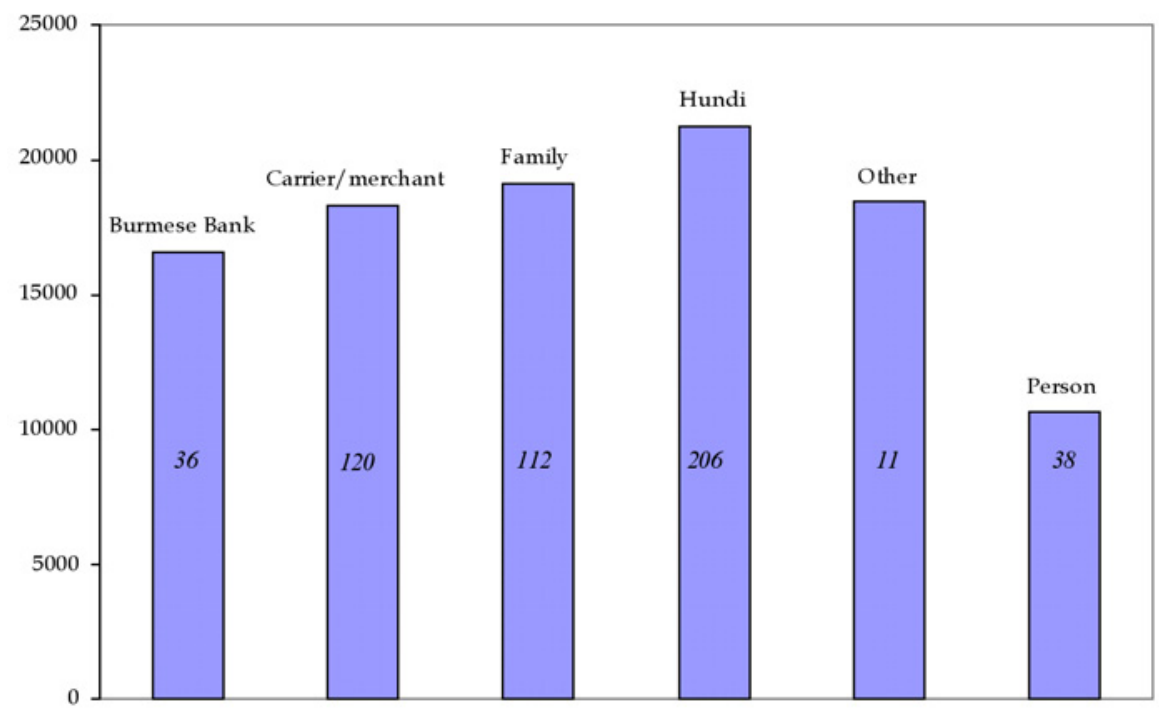

\section{Gender differences}

This survey yields some interesting differences in remittance patterns according to gender, of which the essential finding is that female Burmese migrant workers send home a higher proportion of their income (40 per cent of the maximum) than males (36 per cent). Male workers earn more, but their median annual remittance of Bt15000 is identical to that of female workers. This finding is similar to that of other studies exploring gender differences in remittance patterns in other country pairs (see, for instance, Moreno 2005). The differences are more pronounced among lower-income workers (of which women constitute a larger proportion than the population generally) than among those earning higher 
incomes. Curiously, the survey also reveals differences according to gender in terms of remittance methods and instruments. Women are more likely (18 per cent) to use a bank to send their money home (though the absolute numbers here remain small) and are more likely to send money by hand through another person (25 per cent), but are less likely to use hundi (13 per cent).

Table 5.2 Remittances and gender

\begin{tabular}{|c|c|c|}
\hline Summary measure & Female & Male \\
\hline Sum & Bt3 869 100 & Bt6 164 983 \\
\hline Mean & Bt18 966 & Bt19 488 \\
\hline Median & Bt15 000 & Bt15 000 \\
\hline Mode & Bt10 000 & Bt10 000 \\
\hline Coefficient of variation & $73.9 \%$ & $112.1 \%$ \\
\hline Aggregate ratio to income (2003 maximum) & 0.40 & 0.36 \\
\hline
\end{tabular}

\section{Some conjectures}

This survey reveals that remittances sent from Burmese migrant workers in Thailand directly alleviate the poverty of individuals and households to whom they are sent. Remittances are also likely to provide for individual benefits in allowing greater access to health services and education. Health and education appeared only weakly in our survey results as independent motivations for sending remittances, but it is ventured that both are likely to also reside implicitly within the survival rubric.

The survey also suggests, however, that any national economic development benefits allowed by remittances are largely absent in the Burmese context. The circumstances of Burma's political economy instead undermine the broader processes that might otherwise be apparent.

\section{Remittances and foreign reserves}

As noted at the outset of this chapter, an important benefit often yielded by remittance flows is the extent that they provide sizeable and relatively stable flows of foreign reserves. This attribute is greatly undermined in the Burmese context by the fact that hundi is the most common method by which remittances are made. As demonstrated, hundi works via 'netting' transactions that minimise the flow of foreign exchange.

\section{Remittances and business capital}

Elsewhere, remittances have provided businesses in recipient countries with otherwise scarce capital. Establishing or expanding a business is a strong motivation for remittances in many countries and circumstances. Paying remittances for the purpose of business is not, however, a strong motivating factor in the context of Burma. Even if simple survival was not an all-consuming force, Burma's dire economic and political circumstances would tell against 
substantial investment flows. Indeed, given the risks, it is probably in their own best interests that Burma's migrant workers are unwilling to expose their hard-earned gains in this way.

\section{Remittances and financial development}

The 'leveraging up' of the development potential of remittances through formal financial institutions is much celebrated. Similarly highly regarded is the way that remittance flows might themselves stimulate the development of financial institutions. Unfortunately, these attributes are likewise absent in the circumstances in which Burmese migrant workers find themselves. This is because, first (and as noted above), about 60 per cent of our survey recipients do not possess Thai work permits - a fact that would automatically (legally) rule them out of holding an account at a bank in Thailand. Of course, even among the 40 per cent that do hold work permits, the additional documentation hurdles for opening a bank account remain formidable.

Second, and probably more significant than first-mile obstacles, are the last-mile problems in Burma itself. Put simply, and especially since the banking crisis of 2003, Burma's formal financial system remains distrusted and dysfunctional. Burma's banks eke out a marginal existence in an environment hostile to the survival of financial institutions and they are not an effective instrument to facilitate remittances or, indeed, even to gain from them.

\section{Impact of the 'Saffron Revolution'}

In the wake of what has become widely known as the Saffron Revolution of September-October 2007, money transfers to Burma (of all types) ceased to function. Formal bank-based instruments were suspended in the days of high chaos in September, but in October the impact of US and other international sanctions made even those foreign banks normally happy to do business with Burma think twice. Even the normally extremely resilient hundi system seized up for a few days, including that (central to this chapter) channelling funds from Burmese workers in Thailand. There was, however, a significant difference between the problems faced by the formal and informal systems - the latter being a function not of systemic problems of hundi networks themselves, but of fears that Burma's military regime might resort to its time-honoured practice of suddenly 'demonetising' certain denominations of the kyat. Money transfers to Burma have resumed since the 2007 demonstrations, but the situation remains uncertain and volatile.

\section{Concluding thoughts}

The survey that informs this chapter reveals that the remittances Burmese migrant workers in Thailand send home are large and, circumstances permitting, could provide the means to accelerate Burma's economic development. Unfortunately, 
the survey also reveals that these remittances are employed overwhelmingly in the cause of simple survival, with little in the way of funds left over for investment and other 'productive' purposes that would maximise their development impact. Equally, this chapter finds that remittances to Burma are made overwhelmingly via various informal devices, negating the possibility that they could be 'leveraged up' via formal financial institutions and minimising the dynamic economic effects they might otherwise trigger. Of course, the fact that Burmese migrant-worker remittances are used for bare survival and that they are channelled in informal ways offers yet another window into Burma's dire political economy. In its seminal report on the development possibilities of remittances, the OECD (Straubhaar and Vadean 2005:10) noted that the best way to maximise the impact of remittances on economic growth...is to implement sound macroeconomic policies and policies of good governance... a sound banking system, respect for property rights, and an outward-oriented trade and FDI strategy'. In present-day Burma, such attributes are, alas, highly conspicuous by their absence.

\section{References}

Adams, R. H. 2006, 'Do remittances reduce poverty?', id21 Insights, vol. 60, January.

Adams, R. H. and Page, J. 2005, 'Do international migration and remittances reduce poverty in developing countries', World Development, vol. 33, no. 10, pp. 1645-69.

Aggarwal, R., Demirguc-Kunt, A. and Martinez Peria, M. S. 2006, Do workers' remittances promote financial development?, World Bank Policy Research Working Paper No. 3957, World Bank, Washington, DC.

Amuedo-Dorantes, C., Bansak, C. and Pozo, S. 2005, 'On the remitting patterns of immigrants: evidence from Mexican survey data', Economic Review, First Quarter 2005, Federal Reserve Bank of Atlanta, Atlanta.

Beck, T., Levine, R. and Loayza, N. 2000a, 'Financial intermediation and growth: causality and causes', Journal of Monetary Economics, vol. 46, pp. 31-77.

Beck, T., Levine, R. and Loayza, N. 2000b, 'Finance and the sources of growth', Journal of Financial Economics, vol. 58, pp. 261-300.

Beck, T., Demirgüc-Kunt, A. and Levine, R. 2004, Finance, inequality and poverty: cross-country evidence, NBER Working Paper No. 10979, National Bureau of Economic Research, Cambridge, Massachusetts.

Bolt, P. J. 2000, China and Southeast Asia's Ethnic Chinese: State and diaspora in contemporary Asia, Praeger, Westport, Connecticut.

Bradford, W. and Vicary, A. 2005, 'Preliminary survey results about Burmese migrant workers in Thailand', Burma Economic Watch, 1/2005. 
Clemens, M. 2007, Do visas kill? Health effects of African health professional emigration, Center for Global Development Working Paper No. 114, Center for Global Development, Washington, DC.

Cox, E., Ureta, A. and Ureta, M. 2003, 'International migration, remittances, and schooling: evidence from El Salvador', Journal of Development Economics, vol. 72, pp. 429-61.

de la Garza, R. and Lowell, B. A. 2004, Sending Money Home: Hispanic remittances and community development, Rowman and Littlefield, Oxford.

Financial Action Task Force 2005, Money Laundering and Terrorist Financing Typologies, Organisation for Economic Cooperation and Development, Paris.

Freund, C. and Spatafora, N. 2005, Remittances: transaction costs, determinants, and informal flows, World Bank Policy Research Working Paper No. 3704, World Bank, Washington, DC.

Giuliano, P. and Ruiz-Arranz, M. 2005, Remittances, financial development and growth, IMF Working Paper, WP/05/24, December, International Monetary Fund, Washington, DC.

Gupta, S., Pattillo, C. and Wagh, S. 2007, Impact of remittances on poverty and financial development in Sub-Saharan Africa, IMF Working Paper WP/07/38, February, International Monetary Fund, Washington, DC.

Hastings, A. H. 2006, Entry of MFIs into the remittance market: opportunities and challenges, Paper prepared for the Global Microcredit Summit, 13 November, Halifax, Nova Scotia.

Hildebrandt, N. and McKenzie, D. J. 2005, The effects of migration on child health in Mexico, World Bank Policy Research Working Paper No. 3573, World Bank, Washington, DC.

Inter-American Development Bank (IADB) 2003, Sending Money Home: An international comparison of remittance markets, Inter-American Development Bank, Washington, DC.

International Monetary Fund (IMF) 2002, Balance of Payments Statistics. Yearbook 2002, International Monetary Fund, Washington, DC.

International Monetary Fund (IMF) 2004, Balance of Payments Statistics. Yearbook 2004, International Monetary Fund, Washington, DC.

International Monetary Fund (IMF) 2007, International Financial Statistics, August, International Monetary Fund, Washington, DC.

Kanaiaupuni, S. and Donato, K. M. 1999, 'Migradollars and mortality: the effects of migration on infant survival in Mexico', Demography, vol. 36, pp. 339-53. 
King, R. and Levine, R. 1993, 'Finance and growth: Schumpeter might be right', Quarterly Journal of Economics, vol. 108, pp. 717-37.

Lapper, Richard 2007, 'Cashing in on homeward flows', Financial Times, 28 August 2007.

Levine, R. 1997, 'Financial development and economic growth: views and agenda', Journal of Economic Literature, vol. 35, pp. 688-726.

Levine, R. 2004, Finance and growth: theory and evidence, NBER Working Paper No. 10766, National Bureau of Economic Research, Cambridge, Massachusetts.

Levine, R. and Zervos, S. 1998, 'Stock markets, banks, and growth', American Economic Review, vol. 88, pp. 537-58.

López-Córdova, E. 2005, 'Globalization, migration, and development: the role of Mexican migrant remittances', Economia, vol. 6, pp. 217-56.

Maimbo, S. and Ratha, D. 2005, Remittances: Development impact and future prospects, World Bank, Washington, DC.

Moreno, C. 2005, Gender, remittances and development, Paper presented to the Conference on Women Leaders, 27 September 2005, Haifa, Israel.

Orozco, M. 2006, 'Sending money home: can remittances reduce poverty', id21 Insights, no. 60, January.

Orozco, M. and Fedewa, R. 2006, Leveraging efforts on remittances and financial intermediation, Working Paper 24, Inter-American Development Bank, Washington, DC.

Rajan, R. and Zingales, L. 1998, 'Financial dependence and growth', American Economic Review, vol. 88, pp. 559-86.

Ratha, D. 2005, 'Remittances: a lifeline for development', Finance and Development, vol. 42, no. 4, December.

Spatafora, N. 2005, 'Two current issues facing developing countries', World Economic Outlook, International Monetary Fund, Washington, DC.

Straubhaar, T. and Vadean, F. P. 2005, 'International migrant remittances and their role in development', Migration, Remittances and Development, Organisation for Economic Cooperation and Development, Paris.

Suro, R. 2003, Remittance Senders and Receivers: Tracking the transnational channels, Inter-American Development Bank in collaboration with the Pew Hispanic Center, Washington, DC.

Suro, R., Bendixen, L., Lowell, L. and Benavides, D. C. 2002, Billions in Motion: Latino immigrants, remittances and banking, Pew Hispanic Center, Washington, DC. 
Terry, D. F. and Wilson, S. R. 2005, Beyond Small Change: Making migrant remittances count, Inter-American Development Bank, Washington, DC.

United Nations Development Program (UNDP) 2005, The potential role of remittances in achieving the Millennium Development Goals - an exploration, UNDP Background Note, October, $<$ http://tcdcl.undp.org/Remittances_Oct02005B.pdf>

Vicary, A. 2004, 'Economic survey of "Burmese" working in Thailand: an overview of a BEW project', Burma Economic Watch, 1/2004.

Woodruff, C. and Zenteno, R. 2001, Remittances and microenterprises in Mexico, UCSD Working Paper, University of California, San Diego.

World Bank 2003, Informal Funds Transfer Systems in the APEC Region: Initial findings and a framework for further analysis, World Bank, Washington, DC.

World Bank 2006, Global Economic Prospects 2006: Economic implications of remittances and migration, World Bank, Washington, DC.

World Council of Credit Unions (WOCCU) n.d., A Technical Guide to Remittances, viewed 13 February 2008, <http://www.woccu.org/development/remittances/index.php>

Yang, D. 2005, International migration, human capital, and entrepreneurship: evidence from Philippine migrants' exchange rate shocks, World Bank Policy Research Working Paper No. 3578, World Bank, Washington, DC.

\section{Endnotes}

${ }^{1}$ Surveys of the ever-growing literature on the role of remittances and poverty reduction can be accessed at the web site of the Institute of Development Studies

(<http://www.livelihoods.org/hot_topics/migration/remittancesindex.html\#l $>$ ).

2 For more on the impact of remittances on school attendance, see Yang (2005) and López-Córdova (2005).

3 The Inter-American Development Bank (IADB 2003) found that, for Latin America, 5-10 per cent of remittances were immediately invested in business of some form (and a roughly similar proportion was used for education). Woodruff and Zenteno (2001) estimated that remittances provided about 20 per cent of the capital employed by more than 6000 urban micro-enterprises in Mexico. Yang (2005) and Aggarwal et al. (2006) likewise find evidence of remittances promoting entrepreneurship across many countries and circumstances.

4 Gupta et al. (2007) and Ratha (2005) speculate that developing countries could raise funds on global financial markets by effectively 'securitising' future remittance flows.

5 Empirical analysis by Aggarwal et al. (2006) reports 'a robust positive impact of remittances on financial sector development'. Their study is backed up by a growing number of others suggesting a link between remittances, financial development and economic growth. See, for instance, Guiliano and Ruiz-Arranz (2005) and Gupta et al. (2007).

6 On the role of financial institutions and economic development, see King and Levine (1993), Levine (1997, 2004), Beck et al. (2000a, 2000b) and Rajan and Zingales (1998). With respect to the relatively new findings positing a link between financial-sector development and better outcomes in poverty and inequality, see Beck et al. (2004) and Aggarwal et al. (2006). 
7 According to the UNDP (2005), up to 40 per cent of remittance recipients save at least some of their payments. Savings rates of senders seem to be highly variable according to context. According to Orozco and Fedewa (2006:4) in their work on the Americas, 'on average, around 10\% of remittances received are saved and invested'. For more on the link between savings and subsequent investment decisions, see Gupta et al. (2007:24).

8 FIs around the world have recognised the potential of remittances. BancoSol of Bolivia, one of the world's largest and most successful micro-finance institutions, has a special savings and loan product, 'My Family, My Country, My Return', through which remittance recipients can take out housing loans (Orozco and Fedewa 2006:16). Other mainstream banks and micro-finance providers offer similar products.

9 Nevertheless, collective deals to reduce the fees that money-transfer firms charge micro-finance institutions have been done. For more, see Orozco and Fedewa (2006:13-15). ACLEDA Bank of Cambodia is one micro-finance institution that has partnered with Western Union.

${ }^{10}$ For more on the damaging impact of this brain drain, particularly on national health systems, see Clemens (2007).

11 While Freund and Spatafora (2005) nominate a ratio range of informal to formal mechanisms of between 20 and 200 per cent, in practice, almost any ratio can apply.

12 Western Union's closest competitor (with a global share of about 3 per cent) is MoneyGram, also based in the United States. For more on these firms, their background and their rivalry, see Lapper (2007). Money-transfer firms are especially dominant in the remittances business to Latin America (their share of the important US-Mexico market is about 70 per cent (Amuedo-Dorantes et al. 2005:51).

13 Concerns about the use of hundi systems for money laundering and as a possible vehicle for terrorist financing have heightened greatly in recent years. For a review of some of the issues, see Financial Action Task Force (2005).

14 Suro (2002) also found that an additional 7 per cent of remittance payments in the region were made sending cash through the post. This mechanism could not work in Burma since the postal system scarcely exists in most of the country and, even where it does, it is greatly distrusted.

15 For a comprehensive outline of the survey itself, its methodology and the provinces selected, see Vicary (2004) and Bradford and Vicary (2005).

16 We have assumed an identical ratio of remittance senders to total migrant population identified by our survey. Of course, the figure of 'one million' Burmese in Thailand is not much more than an informed 'guestimate' - albeit, we expect, a conservative one.

17 Investment and GDP data are based on that in IMF (2007).

18 See, for instance, Bolt (2000) for one of but many studies investigating this phenomenon. 